\title{
Comparing diet composition and growth of children living in two limitary Greek islands (Samos and Corfu)
}

\author{
Maria G Grammatikopoulou*, Efstratia Daskalou, Margarita Hatzopoulou, \\ Loukia Sourtzinou and Maria Tsigga \\ Department of Nutrition \& Dietetics, Alexander Technological Educational Institute, PO Box 141, \\ GR-57400 Thessaloniki, Greece
}

Submitted 28 April 2008: Accepted 23 September 2008: First published online 6 November 2008

\begin{abstract}
Objective: The study aimed to assess differences in dietary intake and growth of pre-schoolers and schoolchildren living in two limitary Greek islands; Samos, situated on the eastern border, and Corfu, situated on the western border.

Design: Cross-sectional two-site study.

Methods: A total of 248 children aged 3-12 years from the two islands participated in the survey. Body weight and height were recorded and $Z$-scores were calculated. A $3 \mathrm{~d}$ food record was collected for each child, computer-analysed and compared with the Recommended Daily Allowances (RDA). Intakes $\leq 70 \%$ of the RDA were considered inadequate.

Results: The prevalence of overweight in participants from Samos and Corfu was $10.7 \%$ and $6.5 \%$ respectively, according to the Centers for Disease Control and Prevention growth charts. In Corfu, the diet comprised $52 \%$ carbohydrate, $34 \%$ fat and $14 \%$ protein, all different from the composition of the Samian diet ( $42 \%$ carbohydrate, $39 \%$ fat, $19 \%$ protein; $P \leq 0.05$ ). Inadequacies in micronutrient intake were evident only in the diet of Samos and concerned folate and $\mathrm{P}$ of the pre-schoolers and biotin of the school-aged participants. The diet in Corfu was more similar to the overall Mediterranean pattern as well as that of Italian children. Growth and overweight trends in Corfu resembled the ones in Italy, whereas in Samos, similarities were identified with trends from Turkey.

Conclusions: Border areas at a distance from the mainland exhibit different dietary intakes compared with rest of the country; thus when designing nutrition surveys the setting should also include such limitary areas.
\end{abstract}

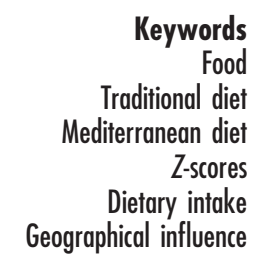

The 'proper' diet for children is of increasing concern as it can ensure proper growth, safeguard future health and minimize the prevalence of obesity. In recent years, Greek children have been affected by a nutrition transition in favour of a more 'Westernized' diet and this has elevated the rates of overweight and obesity ${ }^{(1,2)}$. In order to clarify the nature of children's current diets, research in Greece has focused on dietary intake and growth, with the majority of studies being based in urban areas like Athens or Thessaloniki, or in areas that host a university, like Crete. Recent research involving five different counties within the Greek mainland revealed that $16.0 \%$ of pre-school boys and $15 \cdot 5 \%$ of girls were overweight ${ }^{(3)}$ according to the Centers for Disease Control and Prevention (CDC) growth charts $^{(4)}$. Mamalakis et al. ${ }^{(5)}$ studied the insular population of children in Crete and classified $24.0 \%$ of the boys and $19 \cdot 2 \%$ of the girls as overweight, and $8 \cdot 2 \%$ of the boys and $5 \cdot 0 \%$ of the girls as obese, according to the CDC growth charts. In urban areas of mainland Greece, children were reported to be slimmer. In the city of Thessaloniki, the prevalence of overweight was 31\% in boys and $21 \%$ in girls $^{(6)}$, according to the International Obesity Taskforce criteria $^{(7)}$.

Although ethnicity has been proved to affect children's food consumption in the USA ${ }^{(8)}$ and the European Union $^{(9)}$, the possible influence of geographical residence within the same country has not yet been studied. It has been suggested that the diet of Greeks living a distance from the mainland ${ }^{(10)}$, or in limitary areas, might differ in three ways, by: (i) sustained insistence to traditional dietary habits ${ }^{(11)}$; (ii) being affected by local abundance in production; or (iii) being influenced by neighbouring countries $^{(10)}$. Thus, although Greece is a relatively small country, variations in dietary habits exist and might induce changes in the prevalence of childhood obesity.

The present double-site, cross-sectional study aimed to assess nutrient intake and growth of Greek children living in the border areas. The setting involved two limitary 
islands, Samos and Corfu, situated on the eastern and western border of the country, respectively.

\section{Methods}

\section{Subjects}

The sample consisted of 248 children, aged 3-12 years, from the islands of Samos and Corfu. Samos is situated in the Aegean Sea, on the eastern border with Turkey, and Corfu is situated in the Ionian Sea, on the western border, opposite Italy (Fig. 1). Children were randomly selected from four different public schools in Samos, all from the areas of Karlovasi and Marathokambos. In Corfu, participants were randomly selected through friends and acquaintances from Kanali, Kassiopi and Corfu city. Due to small sample size, both sexes were grouped together. Participants were divided into two groups according to age. The first group comprised seventy-six young children aged 3-6 years (pre-schoolers), thirty-nine girls and thirty-seven boys (mean age 4.86 (SD 0.82 ) years). The second group consisted of 172 older children aged 7-12 years (schoolchildren), ninety-three girls and seventy-nine boys (mean age 9.87 (SD 1.58) years). Eighty-two subjects dropped out during data collection, as the initial sample aimed to recruit 165 participants from each site.

\section{Etbical consent}

Approval for the research was provided from local authorities, the school directors and the Alexander Technological Educational Institute. The same procedures and instruments were used in both islands. Parents were informed of the nature and purpose of the study before giving their consent for participation. Research was self-funded.

\section{Procedure}

A $3 \mathrm{~d}$ food recall (one weekend day and two weekdays), collected via three next-day interviews, was used to assess dietary intake. Recalls were not filled in by the parents alone, as many were illiterate, especially in the island of Samos. Instead, a qualified dietitian interviewed one of the subject's parents, in the presence of the child, in order to collect data. Dietary intake was assessed using the Food Processor computer program version $7 \cdot 4$ (ESHA, Portland, OR, USA) and was expressed as the mean of the three recorded days. Nutrient intake was compared with the sex- and agespecific US Recommended Daily Allowances (RDA) ${ }^{(12)}$ in the absence of Greek RDA values. Intakes less than or equal to $70 \%$ of the RDA were considered inadequate.

Subjects' height was measured with a stadiometer and their weight with an analogue scale that was calibrated regularly (Seca 789). All anthropometric measurements were taken in morning hours (08.00-11.00 hours), in school, by the same experienced physicians. Body fat was not measured, as most participants felt embarrassed to undress in front of their classmates. Data were compared with the latest growth curves for US children ${ }^{(4)}$, as growth

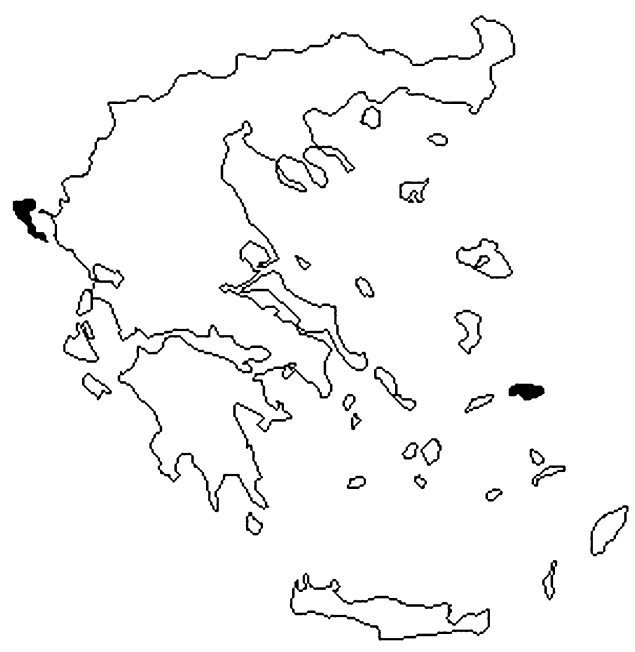

Fig. 1 Study setting: the island of Corfu is situated on the upper western border of Greece and the island of Samos is on the eastern border

curves for Greek children are of questioned validity ${ }^{(13)}$. The Epi Info $3 \cdot 3 \cdot 2$ computer program (CDC, Atlanta, GA, USA) was used for calculating the $Z$-scores of each participant, as $Z$-scores allow for a mixed sexes sample.

\section{Statistical analysis}

Independent-samples $t$ tests were performed in order to assess differences between the two islands. Differences between age groups were omitted, as they would further complicate the results.

\section{Results}

\section{Growtb}

Table 1 presents the anthropometric characteristics of the participants. BMI, weight-for-height $Z$-score (WHZ), body weight and height-for-age $Z$-score (HAZ) were significantly higher in Corfu pre-schoolers $(P \leq 0 \cdot 001$ for the first two and $P \leq 0.05$ for the latter). Among schoolchildren, weight-for-age $Z$-score (WAZ) was significantly higher in Corfu $(P \leq 0 \cdot 001)$.

Only eight $(10 \cdot 1 \%)$ of the participating girls in Samos and seven $(11.3 \%)$ of the boys were overweight according to the CDC growth charts (WAZ $\geq 2$ ) and none was underweight. In Corfu, one girl (1.9\%) and six boys (10.7\%) from the sample were overweight. Thus, a total of $10.7 \%$ and $6.5 \%$ of the participating children living in Samos and Corfu, respectively, were classified as being overweight.

Eleven girls and nine boys in Samos were taller for their age $(H A Z \geq 2)$ and one girl was stunted (HAZ $\leq 2)$. In Corfu, all participants presented normal height for their age.

\section{Dietary intake}

Energy and macronutrient intake is presented in Table 2. The Corfian children demonstrated higher energy, carbohydrate and fibre ( $\mathrm{g} / \mathrm{kg}$ body weight) intakes $(P \leq 0 \cdot 001)$ 
Table 1 Anthropometric characteristics of the study sample: children ( $n$ 248) aged 3-12 years living on the Greek islands of Samos and Corfu

\begin{tabular}{|c|c|c|c|c|c|c|c|c|}
\hline & \multicolumn{4}{|c|}{ Pre-school children } & \multicolumn{4}{|c|}{ Schoolchildren } \\
\hline & \multicolumn{2}{|c|}{ Samos (n 40) } & \multicolumn{2}{|c|}{ Corfu (n 36) } & \multicolumn{2}{|c|}{ Samos (n 100) } & \multicolumn{2}{|c|}{ Corfu (n 72) } \\
\hline & Mean & SD & Mean & SD & Mean & SD & Mean & SD \\
\hline Weight (kg) & $20 \cdot 0$ & $3 \cdot 6$ & $21 \cdot 7^{*}$ & $3 \cdot 3$ & $39 \cdot 2$ & $9 \cdot 1$ & $39 \cdot 5$ & $10 \cdot 3$ \\
\hline Height (m) & $1 \cdot 13$ & $0 \cdot 10$ & $1 \cdot 11$ & 0.07 & $1 \cdot 44$ & $0 \cdot 10$ & $1 \cdot 43$ & $0 \cdot 11$ \\
\hline BMI $\left(\mathrm{kg} / \mathrm{m}^{2}\right)$ & $15 \cdot 78$ & $1 \cdot 77$ & $17 \cdot 33^{\star \star *}$ & $1 \cdot 21$ & $18 \cdot 73$ & $3 \cdot 11$ & $19 \cdot 01$ & 2.56 \\
\hline WAZ & 0.77 & 0.99 & 1.06 & $0 \cdot 62$ & 0.63 & 0.97 & $1 \cdot 44^{\star \star *}$ & $1 \cdot 13$ \\
\hline WHZ & $0 \cdot 14$ & $1 \cdot 35$ & $0.99^{\star \star \star}$ & 0.56 & - & - & - & - \\
\hline $\mathrm{HAZ}$ & 1.59 & $2 \cdot 12$ & $0.67^{\star}$ & 0.76 & 0.69 & $1 \cdot 27$ & 1.02 & 0.79 \\
\hline
\end{tabular}

WAZ, weight-for-age Z-score; WHZ, weight-for-height Z-score; HAZ, height-for-age Z-score.

Mean values were significantly different from those of the children from Samos: ${ }^{\star} P \leq 0 \cdot 05,{ }^{\star \star \star} P \leq 0 \cdot 001$.

Table 2 Energy and macronutrient intake: children ( $n$ 248) aged 3-12 years living on the Greek islands of Samos and Corfu

\begin{tabular}{|c|c|c|c|c|c|c|c|c|}
\hline & \multicolumn{4}{|c|}{ Pre-schoolers } & \multicolumn{4}{|c|}{ Schoolchildren } \\
\hline & \multicolumn{2}{|c|}{ Samos $(n 40)$} & \multicolumn{2}{|c|}{ Corfu (n 36) } & \multicolumn{2}{|c|}{ Samos $(n 100)$} & \multicolumn{2}{|c|}{ Corfu (n 72) } \\
\hline & Mean & SD & Mean & SD & Mean & SD & Mean & SD \\
\hline Energy $(\mathrm{MJ} / \mathrm{d})$ & $6 \cdot 54$ & 1.51 & $7 \cdot 71^{\star \star \star}$ & 0.48 & $6 \cdot 71$ & $1 \cdot 88$ & $9 \cdot 14^{\star \star \star}$ & 0.80 \\
\hline Energy (kcal/kg BW) & $79 \cdot 8$ & $21 \cdot 5$ & $86 \cdot 8$ & 11.9 & $43 \cdot 6$ & $17 \cdot 2$ & $58 \cdot 6^{\star \star \star}$ & $13 \cdot 2$ \\
\hline Protein $(\mathrm{g} / \mathrm{d})$ & $73 \cdot 4$ & $21 \cdot 7$ & $73 \cdot 8$ & $13 \cdot 6$ & $76 \cdot 0$ & $29 \cdot 8$ & $74 \cdot 4$ & $15 \cdot 8$ \\
\hline Carbohydrate $(\mathrm{g} / \mathrm{d})$ & $163 \cdot 8$ & $48 \cdot 8$ & $226 \cdot 4^{\star * *}$ & $30 \cdot 9$ & $154 \cdot 1$ & $56 \cdot 4$ & $299 \cdot 2^{\star * \star}$ & $61 \cdot 9$ \\
\hline Fat $(g / d)$ & $70 \cdot 6$ & $22 \cdot 6$ & $74 \cdot 1$ & $13 \cdot 8$ & $78 \cdot 5$ & $25 \cdot 7$ & $81 \cdot 3$ & $15 \cdot 5$ \\
\hline Fibre $(g / d)$ & $11 \cdot 3$ & $10 \cdot 7$ & $14 \cdot 6$ & $5 \cdot 8$ & $12 \cdot 5$ & $6 \cdot 9$ & $18 \cdot 0^{\star \star \star}$ & $6 \cdot 7$ \\
\hline Fibre (g/kg BW) & 0.05 & 0.07 & $0 \cdot 68^{\star \star \star}$ & 0.26 & 0.34 & $0 \cdot 21$ & $0 \cdot 49^{* * *}$ & 0.23 \\
\hline SFA $(g / d)$ & $27 \cdot 3$ & $8 \cdot 7$ & $22 \cdot 3^{\star}$ & $8 \cdot 8$ & $28 \cdot 7$ & $9 \cdot 8$ & $21 \cdot 5^{\star \star \star}$ & $7 \cdot 1$ \\
\hline MUFA (g/d) & $26 \cdot 8$ & $11 \cdot 0$ & $37 \cdot 4^{\star \star \star}$ & $9 \cdot 1$ & $31 \cdot 2$ & $13 \cdot 8$ & $42 \cdot 8^{\star \star \star}$ & $8 \cdot 7$ \\
\hline MUFA:SFA & 0.99 & 0.32 & $1 \cdot 88^{\star \star *}$ & 0.67 & $1 \cdot 12$ & 0.50 & $2 \cdot 15^{\star \star \star}$ & 0.62 \\
\hline Trans fat $(\mathrm{g} / \mathrm{d})$ & $4 \cdot 1$ & $4 \cdot 7$ & $0 \cdot 7^{\star \star \star}$ & 0.6 & $2 \cdot 6$ & $4 \cdot 0$ & $0 \cdot 6^{\star \star \star}$ & $0 \cdot 1$ \\
\hline$n-3(g / d)$ & $0 \cdot 7$ & $0 \cdot 3$ & 0.6 & 0.5 & $0 \cdot 8$ & 0.5 & 0.9 & $0 \cdot 6$ \\
\hline$n-6(\mathrm{~g} / \mathrm{d})$ & $6 \cdot 7$ & $4 \cdot 4$ & $4 \cdot 7^{\star *}$ & $1 \cdot 2$ & $7 \cdot 0$ & $4 \cdot 4$ & $5 \cdot 7$ & 1.5 \\
\hline Cholesterol $(\mathrm{g} / \mathrm{d})$ & 0.29 & $0 \cdot 15$ & 0.28 & $0 \cdot 19$ & $0 \cdot 28$ & $0 \cdot 15$ & 0.23 & $0 \cdot 15$ \\
\hline
\end{tabular}

BW, body weight.

Mean values were significantly different from those of the children from Samos: ${ }^{\star} P \leq 0 \cdot 05,{ }^{* \star} P \leq 0 \cdot 01,{ }^{\star * *} P \leq 0 \cdot 001$.

in both age groups. Among schoolchildren, the Samians demonstrated a lower absolute fibre intake compared with their peers in Corfu $(P \leq 0 \cdot 001)$.

In terms of clusters of fat intake, boys and girls from Corfu consumed more MUFA $(P \leq 0 \cdot 001)$ than their peers from Samos, but the Samians demonstrated a diet denser in SFA $(P \leq 0.05$ and $P \leq 0.001$ for pre-schoolers and schoolchildren, respectively) as well as in trans fats $(P \leq 0 \cdot 001)$. The MUFA:SFA ratio was significantly higher in the Corfu participants $(P \leq 0 \cdot 001)$. When fat was expressed as a proportion of energy intake, the diet in Samos comprised 16.0 (SD 4.0) \% SFA and 15.1 (sD 3.8) \% MUFA, values significantly different compared with Corfu (18.8 (SD 3.9) \% SFA and 18.3 (sD 4.5) \% MUFA, $P \leq 0 \cdot 001)$. Concerning $n-6$ fatty acids, the only difference was observed in pre-school children $(P \leq 0 \cdot 01)$, with the residents of Samos consuming the most.

Carbohydrate as a percentage of energy intake was significantly higher in the Corfian participants, but protein and fat represented significantly more of the consumed energy in Samos (Fig. 2).
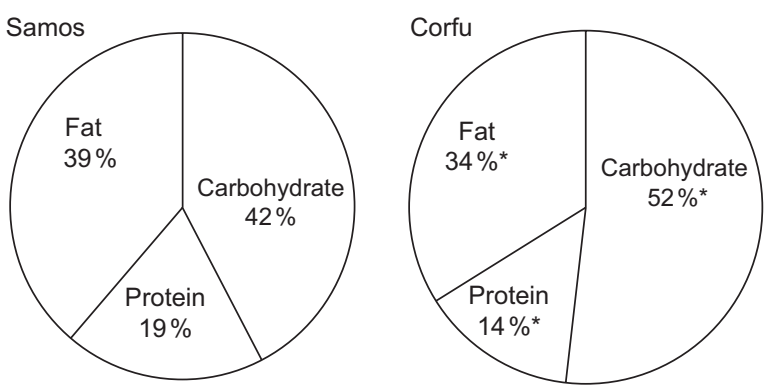

Fig. 2 Macronutrient composition of the diets of children ( $n$ 248) aged 3-12 years living on the Greek islands of Samos and Corfu. Values were significantly different from those of the children from Samos: ${ }^{*} P \leq 0.05$

Inadequacies in micronutrient intake were evident only in the diet of Samos (Table 3) and concerned folate for all of the Samians, P for the pre-school sample and biotin for school-aged participants. Between the islands, the younger participants from Corfu exhibited a higher intake of biotin, folate, $\mathrm{Mg}, \mathrm{P}(P \leq 0 \cdot 001)$ and pantothenic acid 
Table 3 Percentage of the Recommended Daily Allowance for selected micronutrients: children ( $n$ 248) aged 3-12 years living on the Greek islands of Samos and Corfu

\begin{tabular}{|c|c|c|c|c|c|c|c|c|}
\hline & \multicolumn{4}{|c|}{ Pre-schoolers } & \multicolumn{4}{|c|}{ Schoolchildren } \\
\hline & \multicolumn{2}{|c|}{ Samos (n 40) } & \multicolumn{2}{|c|}{ Corfu (n 36) } & \multicolumn{2}{|c|}{ Samos ( $n$ 40) } & \multicolumn{2}{|c|}{ Corfu (n 36) } \\
\hline & Mean & SD & Mean & SD & Mean & SD & Mean & SD \\
\hline Vitamin A & 145 & 128 & 230 & 241 & 178 & 55 & 251 & 76 \\
\hline Vitamin $\mathrm{B}_{1}$ & 182 & 82 & 207 & 70 & 141 & 86 & $171^{\star \star \star}$ & 28 \\
\hline Vitamin $B_{2}$ & 315 & 67 & 344 & 94 & 201 & 67 & $259^{\star \star \star}$ & 134 \\
\hline Niacin & 146 & 76 & 195 & 57 & 110 & 60 & $163^{\star \star *}$ & 60 \\
\hline Vitamin $B_{6}$ & 230 & 88 & 207 & 61 & 146 & 62 & $186^{\star * *}$ & 56 \\
\hline Vitamin $B_{12}$ & 263 & 86 & 308 & 113 & 168 & 126 & $370^{\star \star \star}$ & 117 \\
\hline Biotin & 121 & 42 & $170^{\star \star \star}$ & 52 & 59 & 27 & $101^{\star \star}$ & 157 \\
\hline Vitamin C & 250 & 218 & 235 & 174 & 160 & 149 & $199^{\star \star \star}$ & 154 \\
\hline Vitamin D & 108 & 39 & 140 & 127 & 94 & 60 & $118^{*}$ & 93 \\
\hline Vitamin E & 128 & 99 & 144 & 43 & 86 & 44 & 113 & 29 \\
\hline Folate & 66 & 35 & $149^{\star \star \star}$ & 109 & 51 & 40 & $111^{\star \star *}$ & 35 \\
\hline Pantothenic acid & 120 & 46 & $152^{*}$ & 64 & 78 & 34 & $138^{\star \star *}$ & 65 \\
\hline $\mathrm{Ca}$ & 125 & 31 & 139 & 50 & 70 & 25 & $93^{\star \star \star}$ & 38 \\
\hline $\mathrm{Fe}$ & 107 & 54 & 116 & 47 & 149 & 67 & $190^{\star \star}$ & 121 \\
\hline $\mathrm{Mg}$ & 138 & 40 & $188^{* * *}$ & 31 & 81 & 30 & $140^{\star * \star}$ & 44 \\
\hline $\mathrm{P}$ & 44 & 12 & $252^{\star \star \star}$ & 47 & 95 & 30 & $111^{\star \star \star}$ & 27 \\
\hline $\mathrm{Zn}$ & 168 & 59 & 175 & 32 & 101 & 39 & 118 & 43 \\
\hline lodine & 160 & 57 & 155 & 83 & 87 & 39 & $102^{*}$ & 47 \\
\hline
\end{tabular}

Mean values were significantly different from those of the children from Samos: ${ }^{\star} P \leq 0 \cdot 05,{ }^{\star \star} P \leq 0 \cdot 01,{ }^{\star \star \star} P \leq 0.001$.

$(P \leq 0 \cdot 05)$. In the school-aged sample, children from Corfu consumed more vitamins $\mathrm{B}_{1}, \mathrm{~B}_{2}$, niacin, $\mathrm{B}_{6}, \mathrm{~B}_{12}, \mathrm{C}$, folate and pantothenic acid $(P \leq 0 \cdot 001)$, as well as vitamins $\mathrm{D}(P \leq 0 \cdot 05)$ and biotin $(P \leq 0 \cdot 01) . \mathrm{Mg}, \mathrm{P}$ and $\mathrm{Ca}$ were more adequate in the diet of Corfian schoolchildren $(P \leq 0 \cdot 001)$, as were Fe $(P \leq 0 \cdot 01)$ and iodine $(P \leq 0 \cdot 05)$.

\section{Discussion}

As expected, differences were observed in the diet and growth of children living on the east and west borders of Greece. Overall, children in Corfu presented a diet adequate in energy, macro- and micronutrients and a lower prevalence of overweight. On the other hand, children from Samos demonstrated a higher prevalence of overweight, unbalanced macronutrient distribution and inadequate micronutrient intake.

In the present study none of the participants was underweight or obese, whereas only a small percentage of the participants was overweight $(10 \cdot 7 \%$ and $6.5 \%$ in Samos and Corfu, respectively). In mainland Greece the prevalence of overweight has been reported to be approximately double in a study situated in the north ${ }^{(6)}$ as well as in a nationwide study ${ }^{(14)}$ and triple in the wider Athens county ${ }^{(15)}$. Children of mainland semi-rural Greece $^{(16)}$ have also demonstrated higher BMI values compared with the present sample. However, rural children are generally more active ${ }^{(17)}$, as they have more space to play, and thus the prevalence of overweight is lower. Traffic and criminality limit children's activities in urban areas, as parents are afraid to leave them unattended outside the home ${ }^{(18)}$. In contrast, the setting of the present study - in both Samos and Corfu - included plentiful seaside, small alleys and houses with courtyards, where children can play safely.

Compared with children from neighbouring countries, the Samian participants presented similar overweight rates to children from west Turkey ${ }^{(19,20)}$ with the schoolaged girls demonstrating similar BMI $\left(18.3 \mathrm{~kg} / \mathrm{m}^{2}\right)$ to their Turkish peers ${ }^{(21)}$. However, the high rates of stunting and underweight reported in Turkey were not demonstrated in Samos, as Turkey is still a developing country ${ }^{(20)}$. On the western Greek border, the older children of Corfu exhibited similar prevalence of overweight to residents of urban Tuscany in Italy (7\%) and the present boys also demonstrated similar BMI $\left(18.8 \mathrm{~kg} / \mathrm{m}^{2}\right)$ to Tuscan boys $^{(22)}$. The lower rate of overweight in the participating girls compared with the boys in Corfu has also been reported in northern Italian children ${ }^{(23)}$.

The diet of Samian participants was lower in terms of energy and inadequate in several micronutrients like folate, biotin and P. Similar diets that lead to folic acid deficiency have been reported in girls from Edirne, a city on the west Turkish border ${ }^{(24)}$, within an hour's distance from Samos. The Samian diet included foods high in fat (39\%) and protein (19\%) but low in some micronutrients. Diets with similar fat and cholesterol density, but lower levels of MUFA, have been demonstrated by children living in the semi-rural Volos area in central mainland Greece ${ }^{(16)}$. Such dietary patterns were associated with poorer diet quality, less fibre and vitamins ${ }^{(25)}$. The Samian participants presented significantly lower fibre but higher SFA intake compared with the children from Corfu, indicative of an increased consumption of full-fat dairy products and fatty meats 
but decreased consumption of fruit and vegetables. Moschandreas and Kafatos ${ }^{(26)}$ suggested in Crete that low fibre eaters have higher intakes of saturated fat and this was justified by the present results. In addition, the MUFA:SFA ratio of the Corfian children was closer to the ratio deriving from a traditional Mediterranean diet $(1 \cdot 7)^{(27)}$. The high proportions of MUFA in the examined diets could be explained by the use of olive oil, as olive tree cultivation is common in Greece and favoured by the climate. $\alpha$-Linolenic acid ( $n-3)$, as a marker of fish intake, was similar in both islands. Compared with Turkey, the sample from Samos consumed less carbohydrate but more protein and fat ${ }^{(19,21)}$. It is possible that dietary habits in the island of Samos have been affected by Turkish cuisine, as the island was under Turkish siege for approximately 400 years and hosted many Greek immigrants from the west Turkish coast during the persecution in 1922.

At the other end of Greece, in Corfu, the diet appears to be closer to the Mediterranean recommendations in terms of macronutrient intake. Similar macronutrient content to Corfu's diet has been demonstrated in Italian children ${ }^{(28)}$ since many of the traditional Corfian dishes are affected by Italian cuisine, given the cultural dominance of Venice on the island ${ }^{(10)}$ and the fact that the island was for a long time a Venetian province.

The findings of the present study suggest differences in the diets of children living in the east and west borders of Greece, with the diet in Corfu being more abundant in micronutrients. There is mounting evidence that in limitary areas in distance from the mainland, dietary habits are affected by neighbouring countries. Especially in Samos, where Turkey is closer than any Greek city and transportation is frequent throughout the day, the trade of local goods and herbs is an everyday occurrence. Thus, although mainland Greece might consist of an easy setting for research, border areas ought to be considered when examination of dietary intake and growth is the primary aim of the study.

\section{Acknowledgements}

There are no conflicts of interest concerning the present self-funded manuscript. M.G.G. participated in manuscript composition, protocol design, data analysis and literature review. E.D. conducted data analysis. M.H. and L.S. had equal contribution in recruiting subjects and collecting data. M.T. supervised the study and contributed in the study protocol.

\section{References}

1. Tzotzas T \& Krassas GE (2004) Prevalence and trends of obesity in children and adults of South Europe. Pediatr Endocrinol Rev 1, 448-454.
2. Hassapidou M, Fotiadou E \& Maglara E (1997) A nutrition intervention program for lower secondary schools in Greece. Health Educ J 56, 134-144.

3. Manios Y, Costarelli V, Kolotourou M, Kondakis K, Tzavara C \& Moschonis G (2007) Prevalence of obesity in preschool Greek children, in relation to parental characteristics and region of residence. BMC Public Health 7, 178.

4. Kuczmarski RJ, Ogden CL, Guo SS et al. (2000) CDC growth charts: United States. Adv Data issue 314, 1-28.

5. Mamalakis G, Kafatos A, Manios Y, Anagnostopoulou T \& Apostolaki I (2000) Obesity indices in a cohort of primary school children in Crete: a six year prospective study. Int J Obes Relat Metab Disord 24, 765-771.

6. Hassapidou M, Fotiadou E, Maglara E \& Papadopoulou SK (2006) Energy intake, diet composition, energy expenditure and body fatness of adolescents in Northern Greece. Obesity 14, 855-862.

7. Cole TJ, Bellizzi MC, Flegal KM \& Dietz WH (2000) Establishing a standard definition for child overweight and obesity worldwide: international survey. BMJ $\mathbf{3 2 0}$, 1240-1243.

8. Cullen KW, Baranowski T, Rittenberry L \& Olvera N (2000) Socioal-environmental influences on children's fruit, juice and vegetable consumption as reported by parents: reliability and validity measures. Public Health Nutr 3, 345-356.

9. Lambert J, Agostoni C, Elmadfa I, Hulshof K, Krause E, Livingstone B, Socha P, Pannemans D \& Samartín S (2004) Dietary intake and nutritional status of children and adolescents in Europe. BrJ Nutr 92, Suppl. 2, S147-S211.

10. Ferro-Luzzi A, James WPT \& Kafatos A (2002) The high-fat Greek diet: a recipe for all? Eur J Clin Nutr 56, 796-809.

11. Grammatikopoulou MG, Papadopoulou SK, Zakas A, Mylona A \& Kapsalis I (2006) Dietary intake of free-living elderly in Northern Greece. J Nutr Elder 26, 131-146.

12. Institute of Medicine (2003) Dietary Reference Intakes: Applications in Dietary Planning. Washington, DC: The National Academies Press.

13. Kafatos A (2007) Growth curves for Greek children. Paediatriki 70, 70-74.

14. Georgiadis G \& Nassis GP (2007) Prevalence of overweight and obesity in a national representative sample of Greek children and adolescents. Eur J Clin Nutr 61, 1072-1074.

15. Papadimitriou A, Kounadi D, Konstantinidou M, Xepapadaki P \& Nicolaidou P (2006) Prevalence of obesity in elementary schoolchildren in Northeast Attica. Obesity 14, 1113-1117.

16. Magkos F, Piperkou I, Manios Y et al. (2006) Diet, blood lipid profile and physical activity patterns in primary school children from a semi-rural area of Greece. J Hum Nutr Diet 19, 101-112.

17. Joens-Matre RR, Welk GJ, Calabro MA, Russell DW, Nicklay E \& Hensley LD (2008) Rural-urban differences in physical activity, physical fitness, and overweight prevalence of children. J Rural Health 24, 49-54.

18. Davison KK \& Lawson CT (2006) Do attributes in the physical environment influence children's physical activity? A review of the literature. Int J Behav Nutr Phys Act 3, 19.

19. Manios Y, Kolotourou M, Moschonis G, Sur H, Keskin Y, Kocaoglu B \& Hayran O (2005) Macronutrient intake, physical activity, serum lipids and increased body weight in primary schoolchildren in Istanbul. Pediatr Int $\mathbf{4 7}$, 159-166.

20. Krassas GE, Tsametis C, Baleki V, Constantinidis T, Unluhizarci K, Kurtoglu S, Kelestimur F \& Balkan Group for the Study of Obesity (2004) Prevalence of overweight and obesity among children and adolescents in Thessaloniki-Greece and Kayseri-Turkey. Pediatr Endocrinol Rev 1, Suppl. 3, 460-464.

21. Sur H, Kolotourou M, Dimitriou M, Kocaoglu B, Keskin Y, Hayran O \& Manios Y (2005) Biochemical and behavioral 
indices related to BMI in schoolchildren in urban Turkey. Prev Med 41, 614-621.

22. Tognarelli M, Picciolli P, Vezzosi S, Isola A, Moretti F, Tommassetto E, Laura Fantuzzi A \& Bedogni G (2004) Nutritional status of 8-years old rural and urban Italian children: a study in Pistoia, Tuscany. Int J Food Sci Nutr 55 , 381-387.

23. Pasqui F, Baldini M, Biagi P \& Maranesi M (2006) Dietary habits and related psychological and social factors: influence on the body weight of elementary school children. Int J Food Sci Nutr 57, 159-167.

24. Oner N, Vatansever U, Karasalihoğlu S, Ekuklu G, Celtik C \& Biner B (2006) The prevalence of folic acid deficiency among adolescent girls living in Edirne, Turkey. J Adolesc Health 38, 599-606.
25. Lee Y, Mitchell DC, Smicklas-Wright H \& Birch LL (2001) Diet quality, nutrient intake, weight status, and feeding environments of girls meeting or exceeding recommendations for total dietary fat of the American Academy of Pediatrics. Pediatrics 107, E95.

26. Moschandreas J \& Kafatos A (1999) Food and nutrient intakes of Greek (Cretan) adults. Recent data for foodbased guidelines in Greece. BrJ Nutr 81, Suppl. 2, S71-S76.

27. Trichopoulou A, Costacou T, Bamia C \& Trichopoulos D (2003) Adherence to a Mediterranean diet and survival in a Greek population. $N$ Engl J Med 348, 2599-2608.

28. Verduci E, Radaelli G, Stival G, Salvioni M, Giovannini M \& Scaglioni S (2007) Dietary macronutrient intake during the first 10 years of life in a cohort of Italian children. J Pediatr Gastroenterol Nutr 40, 90-95. 